\title{
Symposium review: Determinants of milk production: Understanding population dynamics in the bovine mammary epithelium*
}

\author{
Anthony V. Capuco ${ }^{1} \dagger \odot$ and Ratan K. Choudhary ${ }^{2}$ \\ ${ }^{1}$ Animal Genomics and Improvement Laboratory, USDA-Agricultural Research Service, Beltsville, MD 20705 \\ ${ }^{2}$ College of Animal Biotechnology, Guru Angad Dev Veterinary and Animal Sciences University, Ludhiana, Punjab 141004, India
}

\begin{abstract}
The mammary gland undergoes distinct periods of growth, development, and secretory activity. During bovine lactation, a gradual decrease in the number of mammary epithelial cells largely accounts for the decline in milk production with advancing lactation. The net decline in cell number (approx. 50\%) is due to cell death but is simultaneously accompanied by cell renewal. Although the rate of cell proliferation is slow, by the end of lactation most cells in the gland were formed after calving. Typically milking is terminated when cows are in the final 2 mo of pregnancy. This causes regenerative involution, wherein extensive cell replacement and mammary growth occurs. We hypothesized that replacement of senescent secretory cells and progenitor cells during the dry period increases milk yield in the next lactation. Analysis of global gene expression revealed networks and canonical pathways during regenerative involution that support cell turnover and mammary growth, and reflect oxidative stress, mitochondrial dysfunction, and endoplasmic reticulum (ER) stress. Immune responses consistent with influx of neutrophils, macrophages, and lymphocytes, and processes that support mammary differentiation and lactogenesis were also evident. Data also suggest that replication of stem and progenitor cells occurs during the dry period. Relying on long-term retention of bromodeoxyuridine-labeled DNA, we identified putative bovine mammary stem cells. These label-retaining epithelial cells (LREC) are in low abundance within mammary epithelium $(<1 \%)$, predominantly estrogen receptor-negative, and localized in a basal or suprabas-
\end{abstract}

Received July 10, 2019.

Accepted September 23, 2019.

*Presented as part of the Lactation Biology Symposium at the ADSA Annual Meeting, Cincinnati, Ohio, June 2019.

†Corresponding author: tony.capuco@gmail.com al layer of the epithelium. Analyses of gene expression in laser-microdissected LREC are consistent with the concept that LREC represent stem cells and progenitor cells, which differ in properties and location within the epithelial layer. We identified potential markers for these cells and have increased their number by infusing xanthosine through the teat canal of prepubertal heifers. Altering population dynamics of mammary stem and progenitor cells during the mammary cycle may be a means to increase efficiency of milk production.

Key words: lactation, regenerative involution, cell turnover, mammary stem cells, ribonucleoside

\section{INTRODUCTION}

The mammary gland is the defining feature of mammalian reproductive strategies. Being tied to the nurturing of offspring, mammary functionality is transient, and it is only after pregnancy that the mammary gland is fully developed. However, at birth the mammary gland is armed with a complement of somatic stem cells and progenitor cells that provide for the developmental changes that begin shortly after birth and for the cyclical changes that occur in synchrony with reproductive cycles. These cyclical changes result from endocrine, nutritional, and management factors associated with reproduction.

The intent of this review is to describe changes in the mammary epithelium during the life cycle of dairy cows and discuss mammary stem cell (MaSC)-based methods to increase milk production efficiency. Data support the importance of cell replacement (turnover) during both lactation and the dry period. Cell turnover, tissue repair, and mammary growth and development depend on the function of MaSC and progenitor cells.

Others in this symposium will describe the regulation of secretory activity and the use of recent advances in stem cell biology, imaging technologies, and comparative genomics to address broad questions about the mammary genome and its regulation. The use of advanced imaging technologies and novel technologies, combined with classical approaches and knowledge, 
offer the promise of providing a wealth of knowledge regarding mammary gland biology that will benefit humankind.

\section{POPULATION DYNAMICS DURING LACTATION}

The amount of milk produced by a mammary gland reflects the number of secretory epithelial cells and the activity per cell. Rates of cell proliferation and cell loss, along with changes in the secretory activity of mammary epithelial cells (MEC), account for the shape of the lactation curve. With the onset of lactation, the metabolic and secretory activity per cell increases as the lactation becomes established. Changes in the secretory epithelium include closure of the tight junctions between adjacent cells (McFadden et al., 1987; Stelwagen et al., 1997; Casey and Plaut, 2007) and increased differentiation of secretory cells, including increased prominence of the endoplasmic reticulum (ER) and mitochondria (Hollmann, 1969; Akers et al., 1981). Strategies to enhance secretory rate, induce cell proliferation, or reduce cell loss can increase milk yield, but what are the relative contributions of these parameters during a normal bovine lactation?

In litter-bearing species, mammary growth during early lactation is quite evident and is crucial to meet the nutrient demands of a suckling litter. Mammary growth during early lactation in sows and rodents may equal the growth that occurs during pregnancy (Hurley, 2001) in response to the suckling stimulus and milk removal (Knight et al., 1984; Hadsell et al., 2006). In contrast, mammary growth during early lactation in dairy ruminants is less pronounced. In dairy goats and sheep, mammary growth during early lactation accounts for approximately $20 \%$ of the total number of mammary cells (Anderson, 1985), but in dairy cows there is little evidence for continued accretion of mammary cells during early lactation (Capuco et al., 2001; Finucane et al., 2008), although increased milking frequency during the first weeks of lactation may elicit a proliferative response in the mammary epithelium and an increase in milk yield that persists after reverting to less-frequent milking (Bar-Peled et al., 1995; Hale et al., 2003). However, others have not confirmed a proliferative response (Wall et al., 2013).

The relative contributions of cellular synthetic capacity and cell number have been evaluated throughout a caprine lactation (Knight and Peaker, 1984). The increase in milk production during early lactation was the result of increased mammary cell number followed by an increase in secretory activity per cell. After peak lactation, decreased milk yield with advancing lactation was primarily the result of declining cell number.
However, during late lactation, when goats were concomitantly pregnant, the secretory activity per cell also declined.

Mammary cell number and secretory activity similarly were analyzed during a bovine lactation, but, importantly, the study included a quantitative evaluation of mammary epithelial cell kinetics (Capuco et al., 2001). Based on measures of total udder DNA in nonpregnant, multiparous cows, increased milk yield during early lactation has been attributed to increased secretory activity per cell, and the decline in milk yield with advancing lactation was attributed to declining cell numbers, with a constant secretory rate. However, when cows are concomitantly lactating and pregnant, a decline in secretory capacity per MEC may occur and is readily apparent during late pregnancy or extended lactation, when the number of MEC increases simultaneously with a rapid decline in milk production. Rates of proliferation and apoptosis were estimated by cellular incorporation of bromodeoxyuridine (BrdU, thymidine analog) and terminal deoxynucleotidyl (dUTP) nick-end labeling (TUNEL), respectively. Rates of mammary cell proliferation were determined by administering multiple injections of $\mathrm{BrdU}$ to label the cells that synthesized DNA within a 24-h labeling period and then quantifying these cells via immunohistochemistry. The 24-h labeling period provided a measure of average daily proliferation rate even in the presence of an underlying diurnal pattern of DNA synthesis, such as that evident in rodent mammary glands (Borst and Mahoney, 1980). The in situ labeling of apoptotic cells in histological sections by TUNEL detects cells with DNA fragmentation that accompanies programmed cell death. Because these labeled cells are present for about $3 \mathrm{~h}$ (Bursch et al., 1990), we multiplied the apoptotic index by 8 to estimate the 24 -h apoptotic rate (Capuco et al., 2001). This provided a proliferation rate of $0.3 \%$ and an apoptotic rate of $0.56 \%$.

The measures of proliferation rate and apoptotic rate accounted for the decline in cell number during lactation. Applying the estimated apoptotic and proliferation rates, we generated curves for cumulative cell loss, cumulative cell proliferation and net cell number (Figure 1; Capuco et al., 2001) We found that (1) the predicted decline in cellular DNA closely approximated the DNA data obtained through chemical assay, and (2) at $252 \mathrm{~d}$ of lactation the MEC present in the gland equaled the number of cells that were formed during lactation. If newly formed cells did not undergo apoptosis within this time frame, then all the cells in the gland were formed during lactation. If that is not the case, then the turnover of epithelial cells will be less, but certainly greater than $50 \%$. Although epithelial cells 

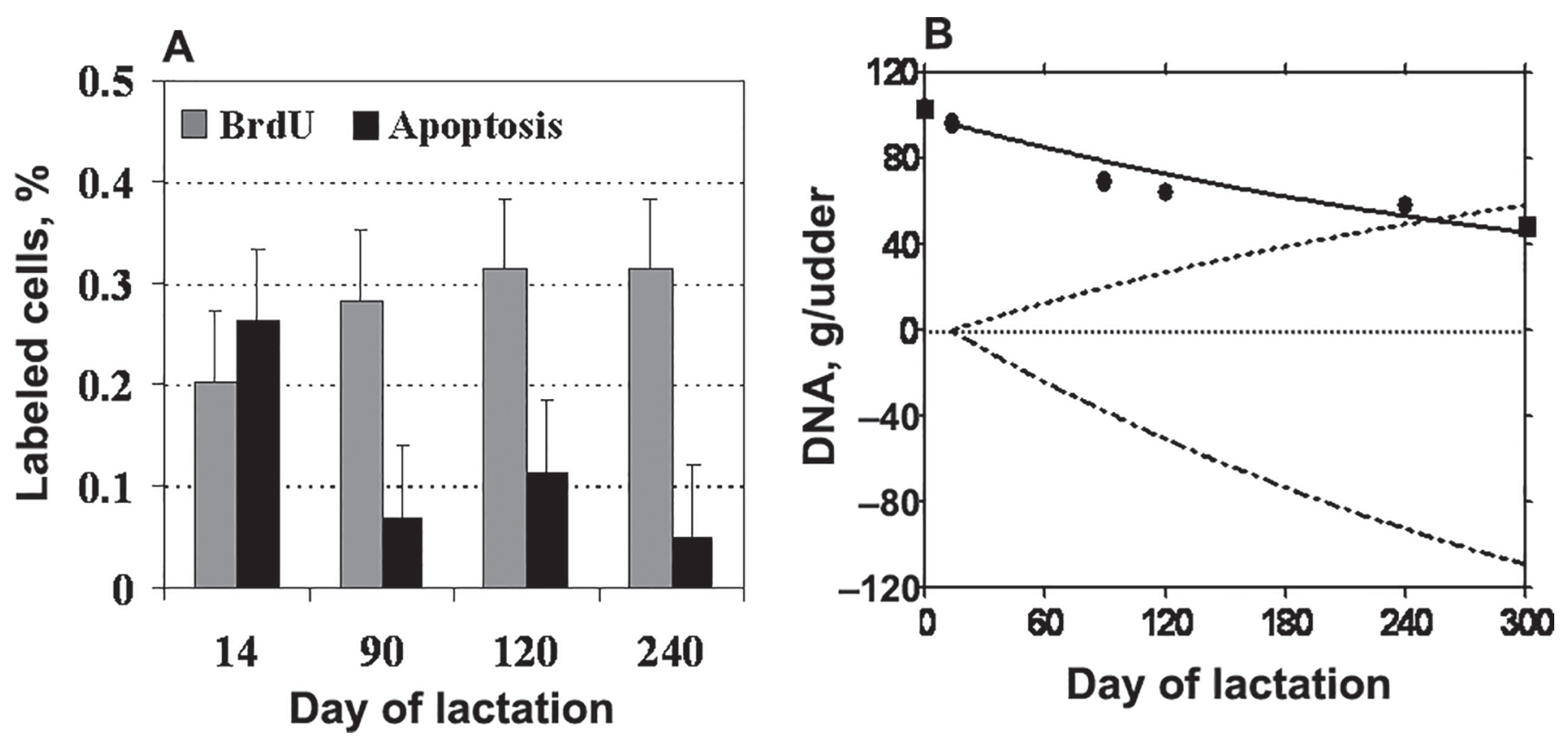

Figure 1. Components of mammary cell (DNA) turnover during lactation. (A) Bromodeoxyuridine (BrdU) and apoptosis labeling indices, mean \pm SE. (B) Curves predicting the DNA content during lactation, based on rates of proliferation (0.003/d) and cell death (0.0056/d) derived from data in panel A. Accumulated synthesis of new DNA (formation of new cells) is indicated by the dotted line. The accumulated loss of DNA by apoptosis is indicated by the dashed-dotted line. Net loss of DNA (difference between synthesis and loss) is shown by the solid line. Experimental data points from 2 experiments are represented by circles and squares in panel B. (Adapted from Capuco et al., 2001.)

can be sloughed into the milk, our measures of SCC and previously reported estimates (Miller et al., 1991) of the proportion of SCC that are epithelial $(<20 \%)$ revealed that this potential route of epithelial loss accounts for less than $2 \%$ of the decline in mammary epithelial DNA. When cows are concomitantly lactating and pregnant, it is likely that a decline in secretory capacity per mammary cell accompanies advanced pregnancy, due to conflicting metabolic demands of gestation and lactation. This is readily apparent during late pregnancy or extended lactation, when the number of MEC increases simultaneously with a rapid decline in milk production.

Although absolute rates of cell proliferation and death during lactation appear to be low, the balance of these processes promotes gradual cell loss but considerable cell turnover during a typically lengthy $(\sim 300 \mathrm{~d})$ bovine lactation. These measures provided the first quantitative demonstration that cell death can account for the decline in mammary cell number and milk yield during lactation (Capuco et al., 2001). In contrast to the cell turnover during a bovine lactation, approximately $75 \%$ of mammary cells are maintained throughout a typical lactation in rats (Pitkow et al., 1972). This lack of extensive cell turnover is probably due to the much shorter length of lactation in rodents than in cows.
Several factors can influence the persistency of lactation and have been described in previous reviews and reports (Capuco et al., 2003; Dahl et al., 2017; Tao et al., 2019). Factors with the potential to enhance persistency of lactation by increasing cell proliferation or decrease cell death include (1) bovine somatotropin (bST) and components of the growth hormone $(\mathrm{GH}) /$ IGF axis; (2) prolactin, through potential interactions with IGF survival activity; (3) photoperiod, likely mediated by prolactin and the IGF axis; (4) increased milking frequency; and (5) antioxidants. Factors that can increase cell death and decrease persistency include (1) mastitis - several stimuli may be involved; (2) neutrophil surveillance activity in the absence of infection; (3) decreased milking frequency; (4) decreased blood flow; (5) stressors, such as heat stress; (6) pregnancy, which, in later stages of gestation, may negatively affect milk production due to competing nutrient partitioning demands and hormonally by apoptotic effects of estrogens. Recently, transcription factor X-box binding protein 1 (XBP1) has been shown to promote expansion of the MEC population in mice and development of the ER compartment during lactation in mice and cows (Davis et al., 2016; Krumm C.S. et al., 2018). The regulation of XBP1 may therefore provide additional clues for enhancing lactation persistency in cows. 


\section{THE DRY PERIOD: REGENERATIVE INVOLUTION}

Knowledge of biological events that occur after cessation of milking provides a foundation for dairy cow management. Conventional management in the United States employs a 40- to 60-d nonlactating interval (dry period) between successive lactations, to optimize milk yield in the next lactation (Swanson, 1965; Kuhn et al., 2006). With continued increases in milk production due to selective breeding and dairy management (milking frequency, photoperiod, nutritional management), knowledge of population dynamics and genetic regulation during the dry period is of increasing importance. This knowledge is also pertinent because appropriate dry-period management is critical for reducing susceptibility to mastitis and metabolic disease during this time of heightened sensitivity (Goff and Horst, 1997; Ingvartsen and Andersen, 2000; Sordillo and Streicher, 2002; Pezeshki et al., 2010).

Milk stasis produced by termination of milking or weaning promotes involution of the mammary glands. Most of our knowledge about mammary involution is derived from use of mouse experimental models (Watson and Kreuzaler, 2011; Wärri et al., 2018). Factors that promote use of murine models include availability of inbred strains to reduce animal variability, amenability to genetic manipulation including transgenics and knockouts, and certainly cost. Almost exclusively, that work has involved weaning nonpregnant mice during peak lactation. This stresses the conversion from a lactating state to a nonlactating state, with synchronization and rapid intensification of regulatory and morphological events. Mammary involution, which is regulated by local and endocrine factors, is characterized by apoptotic death of MEC and their removal by phagocytes, including macrophages and epithelial cells (Li et al., 1997; Fadok, 1999; Wilde et al., 1999). In nonpregnant mice, forced weaning induces apoptosis within $24 \mathrm{~h}$ and irreversible mammary involution within $3 \mathrm{~d}$. Extensive stromal and epithelial remodeling occurs, so that the fully involuted gland resembles that of a virgin mouse (Wilde et al., 1999).

In contrast to the typical mouse model, management of dairy cows (and weaning of mice in the wild) typically involves extensive overlap of lactation and pregnancy. In cows, milking is typically terminated well into the declining phase of lactation and the final months of pregnancy. Furthermore, secretory activity in the mammary gland is heterogeneous, and, particularly in the final days of lactation, there are lobules that exhibit diminished secretory activity and may be targeted for involution (Molenaar et al., 1992, 1995; Capuco and Akers, 1999; Boutinaud et al., 2004). In contrast to mice, reinitiating milking of cows $12 \mathrm{~d}$ after its termination led to nearly complete recovery of milk yield (Hamann and Reichmuth, 1990).

An important modulator of involution is the pregnancy status of the dam (Capuco and Akers, 1999; Capuco et al., 2002). To assess changes in the bovine mammary gland during the dry period, it is important to control for the pregnancy status of the cow. We have used the term regenerative involution (Capuco et al., 2003) to describe the events that occur in the mammary glands of a cow during the dry period (and likely other species that are pregnant when milk stasis occurs), and to distinguish this process from that elicited in mammary glands of nonpregnant mammals subjected to forced involution.

\section{Population Dynamics During Regenerative Involution}

When pregnancy status of dairy cows was regulated in keeping with typical management, an effect of pregnancy on mammary involution, MEC proliferation, and cell turnover was evident (Capuco et al., 1997). The involution stimulus provided by milk stasis was clearly constrained by the mammogenic and lactogenic effects of pregnancy. As described earlier, the mammary gland gradually regresses during lactation so that at dry-off the number of MEC is approximately $50 \%$ of the number present during early lactation. Proliferation of MEC during the dry period is therefore necessary to restore the full complement of MEC before the next lactation, but the process extends beyond restoration of MEC number. We compared aspects of mammary growth in multiparous cows during a conventional 60-d dry period with that in cows that were milked throughout the prepartum period (Figure 2). Total mammary DNA provided no evidence for net cellular regression, and total MEC increased equally in both groups as calving approached. Of significant interest was our finding that DNA synthesis was approximately $80 \%$ greater in dry cows than in lactating cows, which led to the conclusion that this increased DNA synthesis in dry cows was for replacement of existing MEC rather than accretion of additional cells. Additionally, more than $90 \%$ of the proliferating cells were MEC. We hypothesized that this increased cell turnover and renewal during regenerative involution provided for replacement of senescent cells before the next lactation (Capuco et al., 1997; Capuco and Akers, 1999).

Even in the absence of extensive cell loss, considerable tissue remodeling occurs during regenerative involution. Within the epithelial compartment, apoptosis occurs after milk stasis (Quarrie et al., 1996; Wilde 
et al., 1997), along with increased cell proliferation (Capuco et al., 2006), consistent with increased cell turnover of MEC. But changes also occur in synthesis of the connective tissue matrix and composition of its cellular components (Holst et al., 1987; Capuco et al., 1997; De Vries et al., 2010).

\section{Transcriptome Changes During Regenerative Involution}

To obtain additional insight into events occurring during regenerative involution, we performed transcriptome profiling on mammary tissues obtained from 16 euthanized multiparous Holstein cows before and after cessation of milking at $60 \mathrm{~d}$ before expected calving. Tissues were from 4 cows before cessation of milking at $60 \mathrm{~d}$ prepartum and from 3 cows $7,25,40$, and 53 $\mathrm{d}$ after milking was terminated. Transcriptome profiling employed use of a microarray previously described (Li et al., 2006). At $7 \mathrm{~d}$ the transcriptome profile did not differ from that of cows before cessation of milking
(A. V. Capuco, unpublished data). This was likely due to selection of sampling at $d 7$, the small number of replicates, and because lactating cows were at the end of lactation when milking was terminated. However, significant changes in the transcriptome profile were seen at the remaining time points.

The top 5 networks and canonical pathways involving those genes whose expression was differentially altered at 25, 40, and $53 \mathrm{~d}$ after dry-off are listed in Table 1, and the number of genes that pertain to proliferation or cell death are depicted in Figure 3. Several prominent features were evident. First, the processes of cell proliferation and apoptosis proceeded throughout the period of regenerative involution. Second, mitochondrial stress, ER stress, the ubiquitination pathway, and the unfolded protein response (UPR) were important features. Third, involvement of an immune response (also evident in additionally detected pathways and networks) was evident. The heavy involvement of proliferation and apoptosis is consistent with the high rate of cell renewal during regenerative involution. The

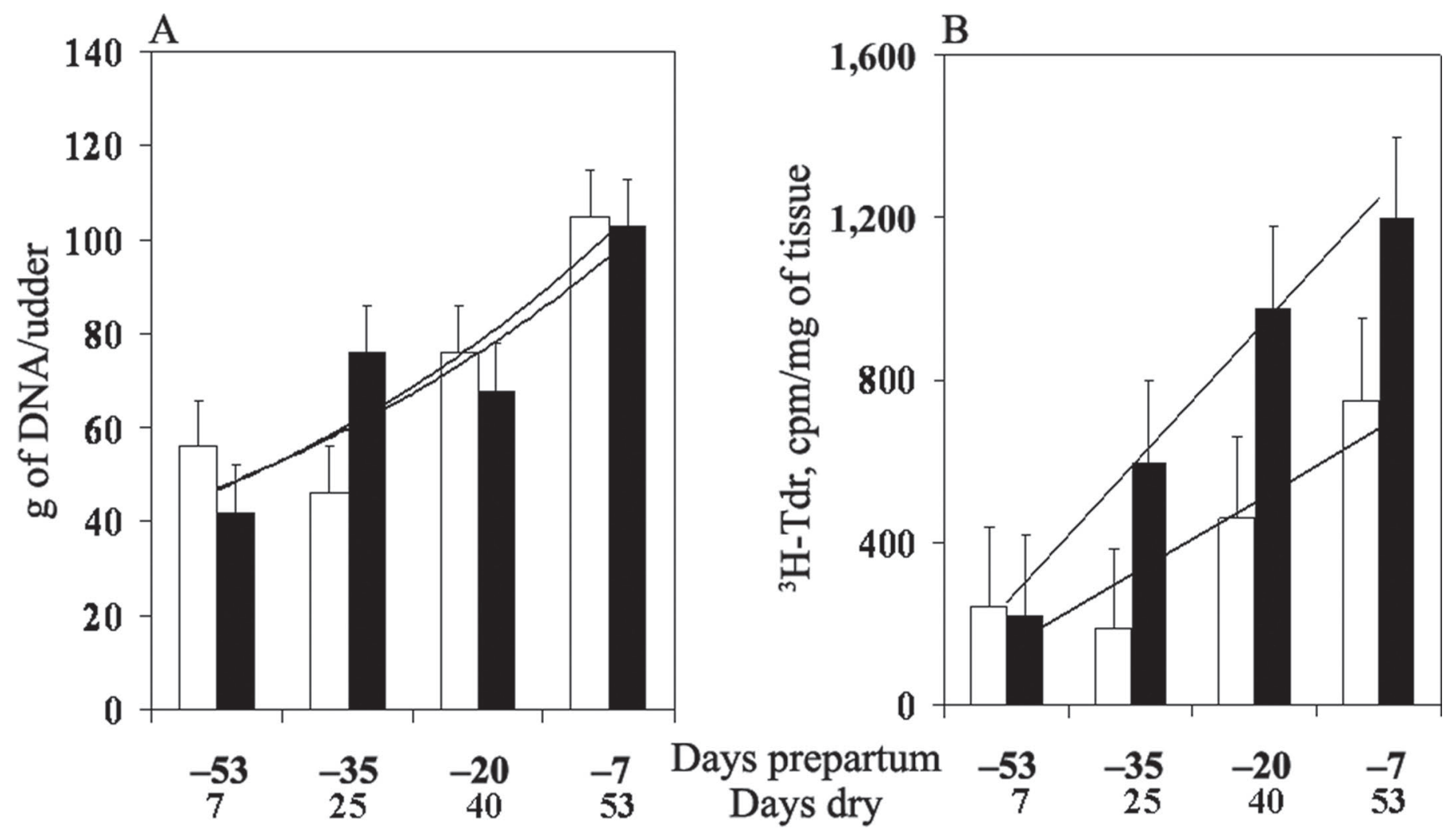

Figure 2. Mammary growth and DNA synthesis in cows that were dried off (solid bars) and those that were continuously milked (open bars) during the prepartum period. Nonlactating cows had milking terminated $60 \mathrm{~d}$ before expected parturition, and lactating cows were milked throughout the prepartum period. Days before expected parturition and days after cessation of milking are indicated on the x-axis. (A) Total DNA content of the udder. (B) In vitro incorporation of ${ }^{3} \mathrm{H}$-thymidine $\left({ }^{3} \mathrm{H}\right.$-Tdr) by mammary tissue. cpm $=$ counts per minute. Data are presented as mean \pm SE. (Adapted from Capuco et al., 1997.) 
UPR is prominent in the transcriptome of lactating mammals and has been hypothesized to be necessary to permit the accumulation of copious amounts of milk proteins within the secretory cell (Lemay et al., 2007). Recently, UPR and ER stress response have been seen as essential features for survival of MEC and for preventing irreversible involution (Wärri et al., 2018), and therefore may promote cell renewal rather than massive cellular death. The ER stress response is largely orchestrated by XBP1 and provides for the detection and management of misfolded proteins in the ER lumen. This prominent response pathway during regenerative involution is depicted in Figure 4.

Because we hypothesized that regenerative involution is important for replacement of senescent cells (perhaps most importantly mammary progenitor cells), we examined our transcriptome data for preliminary evidence in support of that hypothesis. Although selective examination of data can be problematic, we discovered that the abundance of transcripts for inosine- 5 '-monophosphate dehydrogenase 2 (IMPDH2), the rate-limiting enzyme in the de novo synthesis of guanine nucleotides, was increased during regenerative involution. Activity of this enzyme has been implicated in the regulation of MaSC expansion (Paré and Sherley, 2006; Capuco et al., 2009), a topic that we will address in a subsequent section. This increase may foster expansion of the MaSC, mammary growth, and the replacement of senescent cells. Increased transcript abundance for AURKA, P2R14, TEP1, AURKAIP, ITGB1/CD29, and FNDCB are also consistent with this concept.

\section{CELL TURNOVER, CELL DAMAGE, AND CELL SENESCENCE}

Cell turnover or cellular renewal is essential for maintenance of a tissue or organ. Some tissues are characterized by very high rates of cellular replacement, as evidenced by hematopoietic tissue and epithelium of the digestive tract, whereas others, such as the mammary gland, display more modest rates of cell turnover. Furthermore, MEC turnover in the mammary gland is adaptive to the cyclical nature of mammary gland function. Rates of apoptosis and proliferation are modest during a bovine lactation but considerably greater during regenerative involution. In both instances, we suggest that cell turnover provides for replacing senescent or damaged cells and enhances mammary productivity. During a bovine lactation, modest rates of cell turnover may provide for maintenance of secretory activity, so that the decline in milk yield during lactation is due to declining cell number rather than declining secretory activity. During regenerative involution, cell proliferation and apoptosis increase, and mammary growth

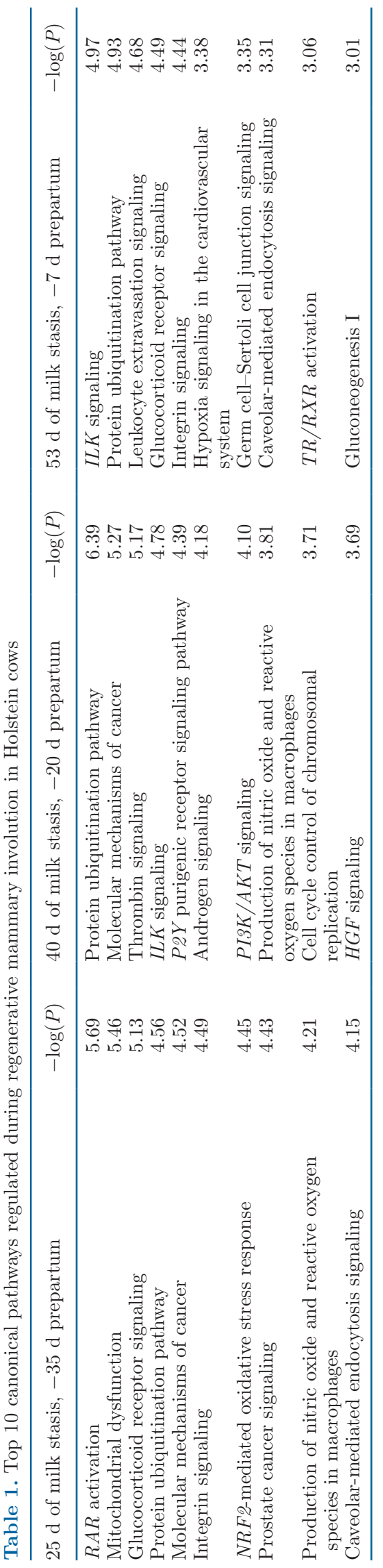




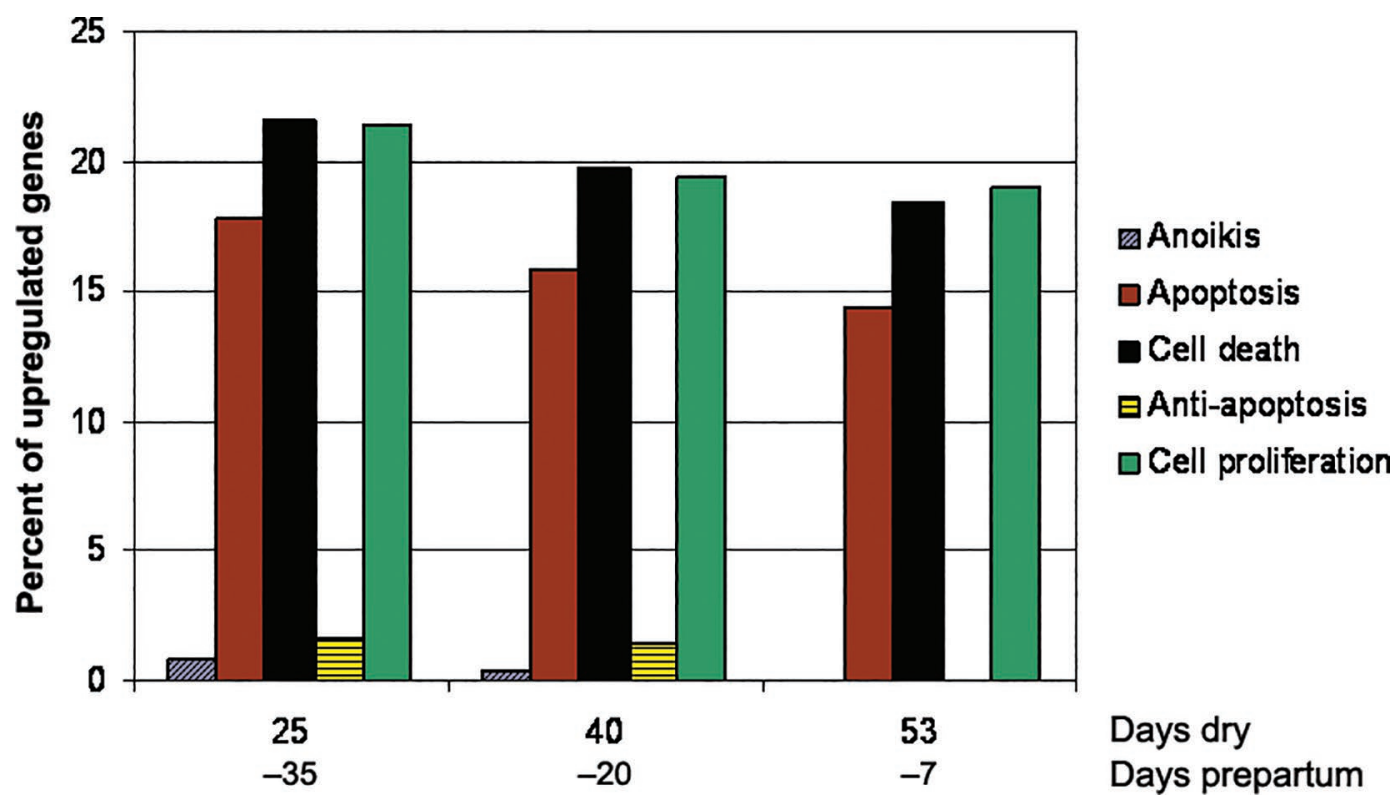

Figure 3. Transcript abundance for genes pertaining to cell death and proliferation that are upregulated in the mammary gland during the dry period versus late lactation. Late-lactation samples were obtained the week before dry-off at $60 \mathrm{~d}$ prepartum. Samples during the dry period were obtained $7,25,40$, and $53 \mathrm{~d}$ after dry-off. Because no differences were noted in the transcript profile at $7 \mathrm{~d}$ dry compared with late lactation, expression at $7 \mathrm{~d}$ dry ( $-53 \mathrm{~d}$ prepartum) is not depicted.

occurs with considerable turnover of the MEC. There is considerable interest in management protocols that may be used to accelerate involution (Zhao et al., 2019), enhance mammary proliferation (Wall et al., 2005; Crawford et al., 2015; Bentley et al., 2015), and reduce the epigenetic effects of heat stress through appropriate cooling measures (Tao et al., 2019) during this critical phase of cell turnover and mammary growth.

What diminished functions may be restored by cell turnover during lactation and regenerative involution? Cellular senescence relates to the accumulation of cell damage that leads to decreased resistance to stress and loss of replicative function (e.g., the Hayflick limit). To maintain functionality, it is necessary to replace damaged secretory cells and cells with diminished proliferative capacity. We hypothesize that the cells that are replaced during lactation are primarily the former, whereas the cells that are replaced during regenerative involution fall into both categories. With regard to diminished proliferative function, we suggest that a dry period is important for replacement of progenitor cells, as these cells provide for mammary proliferation but have a limited life span. Decreased milk yield and persistency of lactation in cows not permitted a dry period is consistent with this concept (Montovani et al., 2010).

Although organs may contain polyploid or aneuploid cells, essentially the genome is consistent throughout the body. Epigenetic regulation accounts for cellular differentiation and, combined with transcriptional and additional post-transcriptional mechanisms, alters gene expression and cellular activity. One might say that epigenetic tags document the lifetime experiences of a cell. Cell turnover in the mammary gland during regenerative involution allows for cleaning the slatethat is, replacing an existing population of cells with cells that have not been affected by past events, such as mastitis (Singh et al., 2012) and oxidative stress (Hadsell et al., 2006), that may depress cell function, and replacing progenitor cells with diminished reproductive capacity. Cellular senescence may result from the ability of various cellular stresses, such as mastitis (Singh et al., 2012) to promote epigenetic tagging, with a cumulative impact that may compromise cell function. It remains to be determined whether stem cells and progenitor cells are resistant, or differentially resistant, to epigenetic effects of stress. A study of the extent of DNA methylation versus chronological age of a variety of tissues suggest that a DNA methylation clock may be valuable in assessing senescence, as is the telomeric clock (Horvath, 2013). The limited lifespan of mammary progenitors versus MaSC may suggest that progenitors are more prone to accumulation of epigenetic effects of environmental stressors than are MaSC. If so, regeneration of mammary progenitors by MaSC would be particularly important. Recent technological 


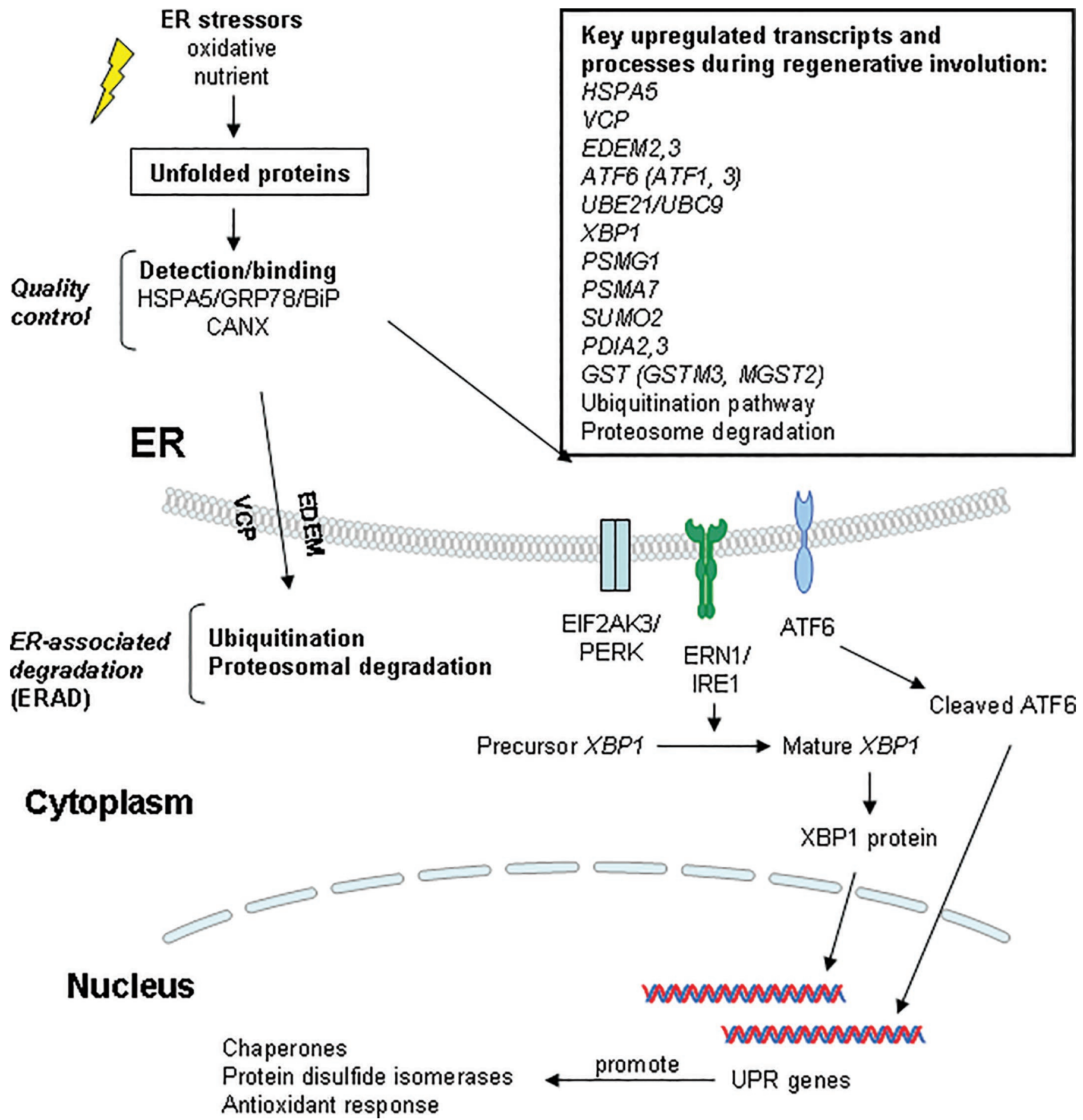

Figure 4. Endoplasmic reticulum (ER) stress pathway is upregulated during regenerative involution. Most secreted proteins and membrane proteins are modified and refold in the lumen of the ER. Correctly folded proteins are transported to the golgi, but misfolded proteins may accumulate in the ER, which is known as ER stress. This may be alleviated by proteasomal degradation or by the unfolded protein response (UPR). The UPR involves activation of genes whose products promote correct folding. When ER stress cannot be resolved, the cell undergoes programmed death. Responses to ER stress and a noninclusive list of key transcripts involved in this response, transcripts that were upregulated at 25,40 , and $53 \mathrm{~d}$ after dry-off $(-35,-20$ and $-7 \mathrm{~d}$ prepartum $)$, are presented in the text box. 
advances that facilitate transcriptome and chromatin studies on individual cells make this line of inquiry feasible. Regardless, it is clear that cell replacement during regenerative involution plays a critical role in maintaining mammary gland function.

\section{MAMMARY STEM CELLS AND PROGENITOR CELLS: IDENTIFICATION AND CHARACTERIZATION OF MASC}

Studies in mice, using cell transplantation techniques, have demonstrated the existence of MaSC and progenitor cells with more limited regeneration capacities, such as ductal and lobule progenitors (Smith, 1996; Shackleton et al., 2006). Initial attempts to characterize these cells were based upon their undifferentiated nature (few cytoplasmic organelles), which imparted light cytoplasmic staining by light or electron microscopy in a variety of species, including bovine (Chepko and Smith, 1997; Ellis and Capuco, 2002). Subsequent investigations have employed additional methods for identifying, collecting, interrogating, and characterizing these cells. Fluorescence-activated cell sorting was used to enrich for cell populations and permit evaluation of their lineage potency. Foremost were initial investigations (Stingl et al., 2006; Shackleton et al., 2006) that employed markers to deplete enzymatically dissociated cells of hematopoietic (CD45 and TER119) and endothelial (CD31) cells and employed markers for epithelial cells that expressed $\beta_{1}$ or $\alpha_{6}$-integrin (CD29 or CD49f), to sort cells with a basal location, and also employed heat-stable antigens (CD24). Cells with greatest regeneration potential were ESR1-negative and expressed CD24 at low levels. Additional insights were gained through lineage-tracing techniques that identified classes of MaSC that populate the epithelium at different stages of development (Van Keymeulen et al., 2011). We refer the reader to other reviews for more detailed coverage of bovine MaSC, progenitor cells, and mammary lineage (Capuco and Ellis, 2013; Finot et al., 2019).

The method that we have employed to identify MaSC in the bovine mammary gland was based on the ability of MaSC to retain BrdU-labeled strands for an extended period due to differential sorting of DNA strands, by which the parental strand is retained by the MaSC during asymmetric division and the newly synthesized strand is relegated to the more differentiated cell (Smith, 2005; Capuco, 2007; Choudhary and Capuco, 2012). Using heifer calves, we administered BrdU and, 5 weeks later, detected label-retaining epithelial cells (LREC) in the basal layer and in embedded layers of the multilayered epithelium of the terminal duct unit. These LREC included ESR1 ${ }^{-}$and ESR $1^{+}$cells. Those in a basal location were ERS1 and presumed to repre- sent MaSC, whereas those in embedded layers were a mixed population of ESR1 $1^{-}$and ESR $1^{+}$cells and were hypothesized to be progenitors (Capuco, 2007).

Others have used flow cytometry to enrich for bovine MaSC and progenitor lineages while permitting assessment of developmental potential (Martignani et al., 2009; Rauner and Barash, 2016; Finot et al., 2019). Multiparameter cell sorting based on expression of surface antigens permits enrichment of cell populations that remain viable and amenable to assessment of their growth and differentiation potentials. Methods to do so have involved assessment of in vitro development of mammospheres or mammary spheroids, or the assessment of development using in vivo transplantation (kidney capsule or cleared mammary fat pad) into immunodeficient mice. These techniques are powerful, but they require awareness of the possible effects of antibodies used in sorting, the effect of evaluating cells under the stress of transplantation and isolation from the stem cell niche, and the ability of a foreign stromal matrix to influence cell-cell interactions (Capuco and Ellis, 2013).

To evaluate gene expression in putative bovine MaSC and progenitors, we employed an alternative approach. The LREC in mammary epithelium were excised from tissue cryosections by in situ laser microdissection and their transcriptomes profiled through microarray hybridization (Choudhary et al., 2013). This approach permitted interrogation of cells in a histological context and without previously removing them from their microenvironment. Gene expression profiles supported the concept that LREC in a basal location represented MaSC, whereas LREC embedded in the epithelium represented progenitors of more committed lineage. As discussed previously (Choudhary et al., 2013) and in the following section, the molecular signatures of these cells provided potential biomarkers (e.g., FNDC3B, NR5A2, and ALDH3B1) and negative biomarkers (e.g., HSPB6, LAMC1) for MaSC and progenitors.

\section{MODULATING MAMMARY STEM CELL ACTIVITY}

The activity of MaSC and progenitor cells is modulated to meet the growth, development, and homeostatic needs of the tissue. Several genetic pathways have been implicated as endogenous regulators of MaSC. Of note, knockout of p53 in mice leads to expansion of MaSC by promotion of symmetric division (Cicalese et al., 2009). Furthermore, the rate of cell renewal in human tissues is indirectly proportional to p53 expression (Seim et al., 2016).

Nontransgenic approaches to promote expansion of adult stem cells have been identified by Sherley and colleagues, who found guanine ribonucleotides to be 
likely regulators. Their in vitro studies with several cell types demonstrated that $\mathrm{p} 53$ promotes asymmetric proliferation of adult stem cells by suppressing expression of inosine-5'-monophosphate dehydrogenase (IMPDH), the rate-limiting enzyme in guanine ribonucleotide synthesis (Rambhatla et al., 2005; Huh et al., 2011; Noh et al., 2011). Furthermore, they demonstrated that this pathway can be bypassed or promoted by exposing cells to guanine nucleotide precursors, xanthosine or inosine, thereby increasing the concentration of guanine ribonucleotides in the cell and increasing stem cell number by promoting symmetric division (Lee et al., 2003; Huh et al., 2011).

We have utilized this approach and evaluated the effect of xanthosine or inosine treatment on bovine MaSC kinetics, with the expectation that it would expand the population of MaSC. Indeed, in vitro treatment of primary MEC with xanthosine promoted symmetrical division, increased the number of putative MaSC, and decreased the population doubling time (Choudhary and Capuco, 2012). Furthermore, exposing the mammary epithelium to xanthosine in vivo, by infusion through the teat canal, resulted in an increase in the number of MaSC and progenitor cells, as assessed by an increase in the number of LREC and a proportional increase in telomerase activity of the tissue (Capuco et al., 2009). Subsequently, others were unable to demonstrate an effect of xanthosine on bovine mammary tissue fragments implanted in cleared fat pads of immunodeficient mice (Rauner and Barash, 2014). The discrepancy remains unresolved but may reflect methodological issues. Still, the overriding question is whether such treatments can influence productivity of dairy animals.

Subsequent studies have evaluated the effect of xanthosine or inosine infusion on milk production. Infusion of inosine into 1 gland of 3 transgenic goats on $\mathrm{d} 5$ to 7 of lactation increased milk yield by $62 \%$ relative to milk production in the control gland (Baldassarre et al., 2011). Similarly, Choudhary and colleagues (Choudhary et al., 2018) infused xanthosine into 1 gland of lactating goats on d 5 to 7 and observed a small but significant increase in milk yield, accompanied by increased expression of milk protein genes and potential stem and progenitor cell markers (ALDH1 and NR5A2). In an attempt to determine whether xanthosine infusion during the prepubertal period would influence mammary growth and future milk production, a half-udder design was employed. Heifers were reared at 2 rates of gain, $0.6 \mathrm{~kg} / \mathrm{d}$ and $1 \mathrm{~kg} / \mathrm{d}$. No effect of xanthosine treatment on milk production was found in either group (A. V. Capuco, unpublished data). A study to determine whether infusion of inosine or xanthosine into the mammary glands of lactating dairy cows will increase milk production has yet to be performed.

\section{CONCLUSIONS}

Changes in population dynamics of the mammary epithelium occur during development and during the lactation cycle. Management procedures that promote cell proliferation and cell turnover, or inhibit cell death at critical times, promote the efficiency of dairy production. Although it remains to be determined whether modulation of MaSC can be readily achieved, such approaches offer the promise of improving milk production efficiency in dairy animals by promoting mammary development prepubertally, enhancing persistency of lactation and the turnover of mammary epithelium during the dry period, and promoting repair of tissue damage resulting from mastitis. Increased understanding of MaSC and the continued advances in tools available for research, including imaging technologies, lineage tracing methodology, molecular, genomic, and bioinformatic tools, and drug delivery systems, provide for a future of exciting advances in mammary gland biology.

\section{REFERENCES}

Akers, R. M., D. E. Bauman, G. T. Goodman, A. V. Capuco, and H. A. Tucker. 1981. Prolactin regulation of cytological differentiation of mammary epithelial cells in periparturient cows. Endocrinology 109:31-40. https://doi.org/10.1210/endo-109-1-31.

Anderson, R. R. 1985. Mammary gland. Pages 3-38 in Lactation. B. L. Larson, ed. The Iowa State University Press, Ames, IA.

Baldassarre, H., J. Deslauriers, N. Neveu, and V. Bordignon. 2011. Detection of endoplasmic reticulum stress markers and production enhancement treatments in transgenic goats expressing recombinant human butyrylcholinesterase. Transgenic Res. 20:1265-1272. https://doi.org/10.1007/s11248-011-9493-y.

Bar-Peled, U., E. Maltz, I. Bruckental, Y. Folman, Y. Kali, H. Gacitua, A. R. Lehrer, C. H. Knight, B. Robinzon, H. Voet, and H. Tagari. 1995. Relationship between frequent milking or suckling in early lactation and milk production of high producing dairy cows. J. Dairy Sci. 78:2726-2736. https://doi.org/10.3168/jds.S0022 -0302(95)76903-X.

Bentley, P. A., E. H. Wall, G. E. Dahl, and T. B. McFadden. 2015. Responses of the mammary transcriptome of dairy cows to altered photoperiod during late gestation. Physiol. Genomics 47:488-499. https://doi.org/10.1152/physiolgenomics.00112.2014.

Borst, D. W., and W. B. Mahoney. 1980. Diurnal changes in mouse mammary gland DNA synthesis. J. Exp. Zool. 214:215-218. https: //doi.org/10.1002/jez.1402140214.

Boutinaud, M., J. Guinard-Flamenta, and H. Jammes. 2004. The number and activity of mammary epithelial cells, determining factors for milk production. Reprod. Nutr. Dev. 44:499-508. https://doi .org/10.1051/rnd:2004054.

Bursch, W., S. Paffe, B. Putz, G. Barthel, and R. Schulte-Hermann. 1990. Determination of the length of the histological stages of apoptosis in normal liver and in altered hepatic foci of rats. Carcinogenesis 11:847-853. https://doi.org/10.1093/carcin/11.5.847.

Capuco, A. V. 2007. Identification of putative bovine mammary epithelial stem cells by their retention of labeled DNA strands. Exp. Biol. Med. (Maywood) 232:1381-1390. https://doi.org/10.3181/ 0703-RM-58.

Capuco, A. V., and R. M. Akers. 1999. Mammary involution in dairy animals. J. Mammary Gland Biol. Neoplasia 4:137-144. https:// doi.org/10.3181/0703-RM-58. 
Capuco, A. V., R. M. Akers, and J. J. Smith. 1997. Mammary growth in Holstein cows during the dry period: Quantification of nucleic acids and histology. J. Dairy Sci. 80:477-487. https://doi.org/10 .3168/jds.S0022-0302(97)75960-5.

Capuco, A. V., E. Annen, A. C. Fitzgerald, S. E. Ellis, and R. J. Collier. 2006. Mammary cell turnover: Relevance to lactation persistency and dry period management. Pages 363-88 in Ruminant Physiology: Digestion, Metabolism and Impact of Nutrition on Gene Expression, Immunology and Stress. K. Sejrsen, T. Hvelplund, and M. O. Nielsen, ed. Wageningen Academic Publishers, Wageningen, The Netherlands.

Capuco, A. V., and S. E. Ellis. 2013. Comparative aspects of mammary gland development and homeostasis. Annu. Rev. Anim. Biosci. 1:179-202. https://doi.org/10.1146/annurev-animal-031412 -103632 .

Capuco, A. V., S. E. Ellis, S. A. Hale, E. Long, R. A. Erdman, X. Zhao, and M. J. Paape. 2003. Lactation persistency: Insights from mammary cell proliferation studies. J. Anim. Sci. 81(Suppl 3):18 31. https://doi.org/10.2527/2003.81suppl_318x.

Capuco, A. V., C. M. Evock-Clover, A. Minuti, and D. L. Wood. 2009. In vivo expansion of the mammary stem/progenitor cell population by xanthosine infusion. Exp. Biol. Med. (Maywood) 234:475482. https://doi.org/10.3181/0811-RM-320.

Capuco, A. V., M. Li, E. Long, S. Ren, K. S. Hruska, K. Schorr, and P. A. Furth. 2002. Concurrent pregnancy retards mammary involution: Effects on apoptosis and proliferation of the mammary epithelium after forced weaning of mice. Biol. Reprod. 66:1471-1476. https://doi.org/10.1095/biolreprod66.5.1471.

Capuco, A. V., D. L. Wood, R. Baldwin, K. McLeod, and M. J. Paape. 2001. Mammary cell number, proliferation, and apoptosis during a bovine lactation: Relation to milk production and effect of bST. J. Dairy Sci. 84:2177-2187. https://doi.org/10.3168/jds.S0022 -0302(01)74664-4.

Casey, T. M., and K. Plaut. 2007. The role of glucocorticoids in secretory activation and milk secretion, a historical perspective. J. Mammary Gland Biol. Neoplasia 12:293-304. https://doi.org/10 .1007/s10911-007-9055-3.

Chepko, G., and G. H. Smith. 1997. Three division-competent, structurally-distinct cell populations contribute to murine mammary epithelial renewal. Tissue Cell 29:239-253. https://doi.org/10 $.1016 / \mathrm{s} 0040-8166(97) 80024-9$.

Choudhary, R. K., and A. V. Capuco. 2012. In vitro expansion of the mammary stem/progenitor cell population by xanthosine treatment. BMC Cell Biol. 13:14. https://doi.org/10.1186/1471-2121 $-13-14$.

Choudhary, R. K., S. Choudhary, D. Pathak, R. Udehiya, R. Verma, S. Kaswan, A. Sharma, D. Gupta, M. Honparkhe, and A. V. Capuco. 2018. Evaluation of xanthosine treatment on gene expression of mammary glands in early lactating goats. J. Dairy Res. 85:288294. https://doi.org/10.1017/S0022029918000493.

Choudhary, R. K., R. W. Li, C. M. Evock-Clover, and A. V. Capuco. 2013. Comparison of the transcriptomes of long-term label retaining-cells and control cells microdissected from mammary epithelium: An initial study to characterize potential stem/progenitor cells. Front. Oncol. 3:21. https://doi.org/10.3389/fonc.2013.00021.

Cicalese, A., G. Bonizzi, C. E. Pasi, M. Faretta, S. Ronzoni, B. Giulini, C. Brisken, S. Minucci, P. P. Di Fiore, and P. G. Pelicci. 2009. The tumor suppressor p53 regulates polarity of self-renewing divisions in mammary stem cells. Cell 138:1083-1095. https://doi.org/10 $.1016 / j . c e l l .2009 .06 .048$.

Crawford, H. M., D. E. Morin, E. H. Wall, T. B. McFadden, and G. E. Dahl. 2015. Evidence for a role of prolactin in mediating effects of photoperiod during the dry period. Animals (Basel) 5:803-820. https://doi.org/10.3390/ani5030385.

Dahl, G. E., S. Tao, and J. Laporta. 2017. Triennial Lactation Symposium/BOLFA: Late gestation heat stress of dairy cattle programs dam and daughter milk production. J. Anim. Sci. 95:5701-5710. https://doi.org/10.2527/jas2017.2006.

Davis, K. R., S. L. Giesy, Q. Long, C. S. Krumm, K. J. Harvatine, and Y. R. Boisclair. 2016. XBP1 regulates the biosynthetic capacity of the mammary gland during lactation by controlling epithelial expansion and endoplasmic reticulum formation. Endocrinology 157:417-428. https://doi.org/10.1210/en.2015-1676.

De Vries, L. D., H. Dover, T. Casey, M. J. VandeHaar, and K. Plaut. 2010. Characterization of mammary stromal remodeling during the dry period. J. Dairy Sci. 93:2433-2443. https://doi.org/10 $.3168 /$ jds.2009-2764.

Ellis, S., and A. V. Capuco. 2002. Cell proliferation in bovine mammary epithelium: Identification of the primary proliferative cell population. Tissue Cell 34:155-163. https://doi.org/10.1016/s0040 -8166(02)00025-3.

Fadok, V. A. 1999. Clearance: The last and often forgotten stage of apoptosis. J. Mammary Gland Biol. Neoplasia 4:203-211. https:// doi.org/10.1023/A:1011384009787.

Finot, L., E. Chanat, and F. Dessauge. 2019. Mammary epithelial cell lineage changes during cow's life. J. Mammary Gland Biol. Neoplasia. 24:185-197. https://doi.org/10.1007/s10911-019-09427-1.

Finucane, K. A., T. B. McFadden, J. P. Bond, J. J. Kennelly, and F. Q. Zhao. 2008. Onset of lactation in the bovine mammary gland: Gene expression profiling indicates a strong inhibition of gene expression in cell proliferation. Funct. Integr. Genomics 8:251-264. https://doi.org/10.1007/s10142-008-0074-y.

Goff, J. P., and R. L. Horst. 1997. Physiological changes at parturition and their relationship to metabolic disorders. J. Dairy Sci. 80:1260-1268. https://doi.org/10.3168/jds.S0022-0302(97)76055 -7 .

Hadsell, D. L., D. Torres, J. George, A. V. Capuco, S. E. Ellis, and M. L. Fiorotto. 2006. Changes in secretory cell turnover, and mitochondrial oxidative damage in the mouse mammary gland during a single prolonged lactation cycle suggest the possibility of accelerated cellular aging. Exp. Gerontol. 41:271-281. https://doi.org/10 .1016/j.exger.2005.12.005.

Hale, S. A., A. V. Capuco, and R. A. Erdman. 2003. Milk yield and mammary growth effects due to increased milking frequency during early lactation. J. Dairy Sci. 86:2061-2071. https://doi.org/10 .3168/jds.S0022-0302(03)73795-3.

Hamann, J., and J. Reichmuth. 1990. Compensatory milk production within the bovine udder: Effects of short-term non-milking of single quarters. J. Dairy Res. 57:17-22. https://doi.org/10.1017/ s002202990002656x.

Hollmann, K. H. 1969. Quantitative electron microscopy of sub-cellular organization in mammary gland cells before and after parturition. Pages 27-41 in Lactogenesis: The Inititation of Milk Secretion of Parturition. M. Reynolds and S. J. Folley, ed. University Pennsylvania Press, Philadelphia, PA.

Holst, B. D., W. L. Hurley, and D. R. Nelson. 1987. Involution of the bovine mammary gland: Histological and ultrastructural changes. J. Dairy Sci. 70:935-944. https://doi.org/10.3168/jds.S0022 -0302(87)80097-8.

Horvath, S. 2013. DNA methylation age of human tissues and cell types. Genome Biol. 14:R115. https://doi.org/10.1186/gb-2013-14 $-10-\mathrm{r} 115$.

Huh, Y. H., J. King, J. Cohen, and J. L. Sherley. 2011. SACK-expanded hair follicle stem cells display asymmetric nuclear Lgr5 expression with non-random sister chromatid segregation. Sci. Rep. 1:176. https://doi.org/10.1038/srep00176.

Hurley, W. L. 2001. Mammary gland growth in the lactating sow. Livest. Prod. Sci. 70:149-157. https://doi.org/10.1016/S0301 $-6226(01) 00208-1$.

Ingvartsen, K. L., and J. B. Andersen. 2000. Integration of metabolism and intake regulation: A review focusing on periparturient animals. J. Dairy Sci. 83:1573-1597. https://doi.org/10.3168/jds .S0022-0302(00)75029-6.

Knight, C. H., A. H. Docherty, and M. Peaker. 1984. Milk yield in rats in relation to activity and size of the mammary secretory cell population. J. Dairy Res. 51:29-35. https://doi.org/10.1017/ s0022029900023293.

Knight, C. H., and M. Peaker. 1984. Mammary development and regression during lactation in goats in relation to milk secretion. Q. 
J. Exp. Physiol. 69:331-338. https://doi.org/10.1113/expphysiol .1984.sp002809.

Krumm, C. S., S. L. Giesy, C. L. Orndorff, and Y. R. Boisclair. 2018. Variation in $\mathrm{x}$-box binding protein 1 (XBP1) expression and its dependent endoplasmic reticulum chaperones does not regulate adiponectin secretion in dairy cows. J. Dairy Sci. 101:5559-5570. https://doi.org/10.3168/jds.2017-14048.

Kuhn, M. T., J. L. Hutchison, and H. D. Norman. 2006. Dry period length to maximize production across adjacent lactations and lifetime production. J. Dairy Sci. 89:1713-1722. https://doi.org/10 .3168/jds.S0022-0302(06)72239-1.

Lee, H. S., G. G. Crane, J. R. Merok, J. R. Tunstead, N. L. Hatch, K. Panchalingam, M. J. Powers, L. G. Griffith, and J. L. Sherley. 2003. Clonal expansion of adult rat hepatic stem cell lines by suppression of asymmetric cell kinetics (SACK). Biotechnol. Bioeng. 83:760-771. https://doi.org/10.1002/bit.10727.

Lemay, D. G., M. C. Neville, M. C. Rudolph, K. S. Pollard, and J. B. German. 2007. Gene regulatory networks in lactation: Identification of global principles using bioinformatics. BMC Syst. Biol. 1:56. https://doi.org/10.1186/1752-0509-1-56.

Li, M., X. Liu, G. Robinson, U. Bar-Peled, K. U. Wagner, W. S. Young, L. Hennighausen, and P. A. Furth. 1997. Mammary-derived signals activate programmed cell death during the first stage of mammary gland involution. Proc. Natl. Acad. Sci. USA 94:3425-3430. https: //doi.org/10.1073/pnas.94.7.3425.

Li, R. W., M. J. Meyer, C. P. Van Tassell, T. S. Sonstegard, E. E. Connor, M. E. Van Amburgh, Y. R. Boisclair, and A. V. Capuco. 2006. Identification of estrogen-responsive genes in the parenchyma and fat pad of the bovine mammary gland by microarray analysis. Physiol. Genomics 27:42-53. https://doi.org/10.1152/ physiolgenomics.00032.2006.

Martignani, E., P. Eirew, C. Eaves, and M. Baratta. 2009. Functional identification of bovine mammary epithelial stem/progenitor cells. Vet. Res. Commun. 33(Suppl 1):101-103. https://doi.org/10.1007/ s11259-009-9254-z.

McFadden, T. B., R. M. Akers, and G. W. Kazmer. 1987. Alpha-lactalbumin in bovine serum: Relationships with udder development and function. J. Dairy Sci. 70:259-264. https://doi.org/10.3168/ jds.S0022-0302(87)80005-X.

Miller, R. H., M. J. Paape, and L. A. Fulton. 1991. Variation in milk somatic cells of heifers at first calving. J. Dairy Sci. 74:3782-3790. https://doi.org/10.3168/jds.S0022-0302(91)78570-6.

Molenaar, A. J., S. R. Davis, L. J. Jack, and R. J. Wilkins. 1995. Expression of the butyrophilin gene, a milk fat globule membrane protein, is associated with the expression of the alpha S1casein gene. Histochem. J. 27:388-394. https://doi.org/10.1007/BF02389025.

Molenaar, A. J., S. R. Davis, and R. J. Wilkins. 1992. Expression of alpha-lactalbumin, alpha-S1-casein, and lactoferrin genes is heterogeneous in sheep and cattle mammary tissue. J. Histochem. Cytochem. 40:611-618. https://doi.org/10.1177/40.5.1374090.

Montovani, R., L. Marinelli, L. Bailoni, G. Gabai, and G. Bittante. 2010. Omission of dry period and effects on the subsequent lactation curve and on milk quality around calving in Italian Holstein cows. Ital. J. Anim. Sci. 9:e20. https://doi.org/10.4081/ijas.2010 .e20.

Noh, M., J. L. Smith, Y. H. Huh, and J. L. Sherley. 2011. A resource for discovering specific and universal biomarkers for distributed stem cells. PLoS One 6:e22077. https://doi.org/10.1371/journal .pone.0022077.

Paré, J. F., and J. L. Sherley. 2006. Biological principles for ex vivo adult stem cell expansion. Curr. Top. Dev. Biol. 73:141-171. https: //doi.org/10.1016/S0070-2153(05)73005-2.

Pezeshki, A., A. V. Capuco, B. De Spiegeleer, L. Peelman, M. Stevens, R. J. Collier, and C. Burvenich. 2010. An integrated view on how the management of the dry period length of lactating cows could affect mammary biology and defence. J. Anim. Physiol. Anim. Nutr. (Berl.) 94:e7-e30. https://doi.org/10.1111/j.1439-0396.2010 .00991.x.

Pitkow, H. S., R. P. Reece, and G. L. Waszilycsak. 1972. The integrity of mammary alveolar cells in two consecutive lactations. Proc. Soc.
Exp. Biol. Med. 139:845-850. https://doi.org/10.3181/00379727 $-139-36250$.

Quarrie, L. H., C. V. P. Addey, and C. J. Wilde. 1996. Programmed cell death during mammary tissue involution induced by weaning, litter removal, and milk stasis. J. Cell. Physiol. 168:559-569. https: //doi.org/10.1002/(SICI)1097-4652(199609)168:3<559::AID$\mathrm{JCP} 8>3.0 . \mathrm{CO} ; 2-\mathrm{O}$.

Rambhatla, L., S. Ram-Mohan, J. J. Cheng, and J. L. Sherley. 2005. Immortal DNA strand cosegregation requires p53/IMPDH-dependent asymmetric self-renewal associated with adult stem cells. Cancer Res. 65:3155-3161. https://doi.org/10.1158/0008-5472 .CAN-04-3161.

Rauner, G., and I. Barash. 2014. Xanthosine administration does not affect the proportion of epithelial stem cells in bovine mammary tissue, but has a latent negative effect on cell proliferation. Exp. Cell Res. 328:186-196. https://doi.org/10.1016/j.yexcr.2014.06 .017 .

Rauner, G., and I. Barash. 2016. Enrichment for repopulating cells and identification of differentiation markers in the bovine mammary gland. J. Mammary Gland Biol. Neoplasia 21:41-49. https://doi .org/10.1007/s10911-015-9348-x.

Seim, I., S. Ma, and V. N. Gladyshev. 2016. Gene expression signatures of human cell and tissue longevity. NPJ Aging Mech. Dis. 2:16014. https://doi.org/10.1038/npjamd.2016.14.

Shackleton, M., F. Vaillant, K. J. Simpson, J. Stingl, G. K. Smyth, M. L. Asselin-Labat, L. Wu, G. J. Lindeman, and J. E. Visvader. 2006. Generation of a functional mammary gland from a single stem cell. Nature 439:84-88. https://doi.org/10.1038/nature04372.

Singh, K., A. J. Molenaar, K. M. Swanson, B. Gudex, J. A. Arias, R. A. Erdman, and K. Stelwagen. 2012. Epigenetics: A possible role in acute and transgenerational regulation of dairy cow milk production. Animal 6:375-381. https://doi.org/10.1017/ S1751731111002564.

Smith, G. H. 1996. Experimental mammary epithelial morphogenesis in an in vivo model: Evidence for distinct cellular progenitors of the ductal and lobular phenotype. Breast Cancer Res. Treat. 39:21-31. https://doi.org/10.1007/bf01806075.

Smith, G. H. 2005. Label-retaining epithelial cells in mouse mammary gland divide asymmetrically and retain their template DNA strands. Development 132:681-687. https://doi.org/10.1242/dev .01609 .

Sordillo, L. M., and K. L. Streicher. 2002. Mammary gland immunity and mastitis susceptibility. J. Mammary Gland Biol. Neoplasia 7:135-146. https://doi.org/10.1023/A:1020347818725.

Stelwagen, K., V. C. Farr, H. A. McFadden, C. G. Prosser, and S. R. Davis. 1997. Time course of milk accumulation-induced opening of mammary tight junctions, and blood clearance of milk components. Am. J. Physiol. 273:R379-R386. https://doi.org/10.1152/ ajpregu.1997.273.1.R379.

Stingl, J., P. Eirew, I. Ricketson, M. Shackleton, F. Vaillant, D. Choi, H. I. Li, and C. J. Eaves. 2006. Purification and unique properties of mammary epithelial stem cells. Nature 439:993-997. https://doi .org/10.1038/nature04496.

Swanson, E. W. 1965. Comparing continuous milking with sixty-day dry periods in successive lactations. J. Dairy Sci. 48:1205-1209. https://doi.org/10.3168/jds.S0022-0302(65)88428-4.

Tao, S., G. E. Dahl, J. Laporta, J. K. Bernard, R. M. Orellana Rivas, and T. N. Marins. 2019. Physiology symposium: Effects of heat stress during late gestation on the dam and its calf. J. Anim. Sci. 97:2245-2257. https://doi.org/10.1093/jas/skz061.

Van Keymeulen, A., A. S. Rocha, M. Ousset, B. Beck, G. Bouvencourt, J. Rock, N. Sharma, S. Dekoninck, and C. Blanpain. 2011. Distinct stem cells contribute to mammary gland development and maintenance. Nature 479:189-193. https://doi.org/10.1038/ nature10573.

Wall, E. H., T. L. Auchtung-Montgomery, G. E. Dahl, and T. B. McFadden. 2005. Short communication: Short-day photoperiod during the dry period decreases expression of suppressors of cytokine signaling in mammary gland of dairy cows. J. Dairy Sci. 88:31453148. https://doi.org/10.3168/jds.S0022-0302(05)72997-0. 
Wall, E. H., J. P. Bond, and T. B. McFadden. 2013. Milk yield responses to changes in milking frequency during early lactation are associated with coordinated and persistent changes in mammary gene expression. BMC Genomics 14:296. https://doi.org/10.1186/ 1471-2164-14-296.

Wärri, A., K. L. Cook, R. Hu, L. Jin, A. Zwart, D. R. Soto-Pantoja, J. Liu, T. Finkel, and R. Clarke. 2018. Autophagy and unfolded protein response (UPR) regulate mammary gland involution by restraining apoptosis-driven irreversible changes. Cell Death Discov. 4:40. https://doi.org/10.1038/s41420-018-0105-y.

Watson, C. J., and P. A. Kreuzaler. 2011. Remodeling mechanisms of the mammary gland during involution. Int. J. Dev. Biol. 55:757762. https://doi.org/10.1387/ijdb.113414cw.

Wilde, C. J., C. V. P. Addey, P. Li, and D. G. Fernig. 1997. Programmed cell death in bovine mammary tissue during lactation and involution. Exp. Physiol. 82:943-953. https://doi.org/10 .1113/expphysiol.1997.sp004075.

Wilde, C. J., C. H. Knight, and D. J. Flint. 1999. Control of milk secretion and apoptosis during mammary involution. J. Mammary Gland Biol. Neoplasia 4:129-136. https://doi.org/10.1023/ A:1018717006152.

Zhao, X., B. Ponchon, S. Lanctôt, and P. Lacasse. 2019. Invited review: Accelerating mammary gland involution after drying-off in dairy cattle. J. Dairy Sci. 102:6701-6717. https://doi.org/10.3168/ jds.2019-16377.

\section{ORCIDS}

Anthony V. Capuco @i https://orcid.org/0000-0001-9443-2047 